infants with endotoxin shock the clearance of fat from the circulation may be defective and, therefore, fat should be administered with care.

\section{REFERENCES}

1. Andrew G, Chan G, Schiff D 1978 Lipid metabolism in the neonate. III. The ketogenic effect of intralipid infusion in the neonate. J Pediatr 92:995

2. Cheung MC, Albers JJ 1977 The measurement of apolipoprotein A-I and A-II levels in men and women by immunoassay. J Clin Invest $60: 43$

3. Dhanireddy R, Hamosh M, Sivesubramanian KN, Chowdhry P, Scanlon JW Hamosh P 1981 Postheparin lipolytic activity and intralipid clearance in very-low-birth-weight infants. J Pediatr 98:617

4. Filler R, Takada Y, Carreras T, Heim T 1980 Serum intraplipid levels in neonates during parenteral nutrition: the relation to gestation age. $J$ Pediatr Surg 15:405

5. Goldberg IJ, Le NA, Paterniti JR Jr, Ginsberg HN, Lindgren FT, Brown WV 1982 Lipoprotein metabolism during acute inhibition of hepatic triglyceride lipase in the cynomolgus monkey. $\mathbf{J}$ Clin Invest 70:1184

6. Huttunen JK, Ehnholm C, Kinnunen PKJ, Nikkilä EA 1975 An immunochemical method for the selective measurement of two triglyceride lipase in human postheparin plasma. Clin Chim Acta 63:335

7. Högstedt B, Lindquist B 1963 Lipoprotein lipase in plasma of the normal newborn. Acta Paediatr Scand 52:61

8. Jansen H, van Tol A, Hülsmann WC 1980: On the metabolic function of heparin-releasable liver lipase. Biochem Biophys Res Commun 92:53

9. Kawakami M, Pekala PH, Lane MD, Cerami A 1982 Lipoprotein lipase suppression in 3T3-L1 cells by an endotoxin-induced mediator from exudate cells. Proc Natl Acad Sci USA 79:912

10. Lanza-Jacoby S, Lansey SC, Cleary MP, Rasato FE 1982 Alterations in lipogenic enzymes and lipoprotein lipase activity during Gram-negative sepsis in the rat. Arch Surg 117:1.44

11. Murase $\mathrm{T}$, Itakura $\mathrm{H} 1981$ Accumulation of intermediate density lipoprotein in plasma after intravenous administration of hepatic triglyceride lipase antibody in rats. Atherosclerosis 39:293

12. Nikkilä EA, Kuusi T, Taskinen MR 1982 Role of lipoprotein lipase and hepatic endothelial lipase in the metabolism of high density lipoproteins: a novel concept on cholesterol transport in HDL cycle. In: Carson A, Pernow B (eds) Metabolic Risk Factors in Ischemic Cardiovascular Disease. Raven Press, New York, pp 205-215

13. Nilsson-Ehle P 1982 Regulation of lipoprotein lipase. In: Carlson A, Pernow $\mathrm{B}$ (eds) Metabolic Risk Factors in Ischemic Cardiovascular Diseases. Raven Press, New York, pp 49-57

14. Olegård R, Gustafson A, Kjellmer I, Victorin L 1975 Nutrition in low-birthweight infants. III. Lipolysis and free fatty acid elimination after intravenous administration of fat emulsion. Acta Paediatr Scand 64:745

15. Reidy MA, Schwartz SM 1983 Endothelial injury and regeneration. IV. Endotoxin: a nondenuding injury to aortic endothelium. Lab Invest 48:25

16. Rovamo L, Taskinen MR, Kuusi T, Nikkilä EA, Ehnholm C, Raivio KO 1984 Postheparin plasma lipase activities and plasma lipoproteins in newborn infants. Pediatr Res 18:642

17. Shennan AT, Bryan MH, Angel A 1977 The effect of gestational age on intralipid tolerance in newborn infants. $\mathrm{J}$ Pediatr 91:134

18. Tan MH 1978 The lipoprotein lipase system: new understandings. Can Med Assoc J 118:675

19. Togari $\mathrm{H}$, Mikawa $M$, Iwanaga $T$, Matsumotto $N$, Kawase A, Hagisawa $M$, Ogino T, Goto R, Watanabe I, Kito H, Ogawa Y, Wada T 1983 Endotoxin clearance by exchange blood transfusion in septic shock neonates. Acta Paediatr Scand 72:87

20. Zaidan H, Dhanireddy R, Hamosh M, Pramanik AK, Chowdhry P, Hamosh P 1982 Effect of continous heparin administration on intralipid clearing in very-low-birth-weight infants. J Pediatr 101:599

\title{
Carbohydrate Tolerance in Cystic Fibrosis Is Closely Linked to Pancreatic Exocrine Function
}

\author{
MITCHELL E. GEFFNER, BARBARA M. LIPPE, SOLOMON A. KAPLAN, ROBERT M. ITAMI, \\ BAIBA K. GILLARD, SEYMOUR R. LEVIN, AND IAN L. TAYLOR \\ Divisions of Pediatric Endocrinology [M.E.G., B.M.L., S.A.K., R.M.I.] and Pediatric Hematology [B.K.G.], \\ University of California, Los Angeles, Medical Center, Veterans Administration Wadsworth Medical Center, \\ University of California, Los Angeles School of Medicine [S.R.L.], and Veterans Administration Sepulveda \\ Medical Center, University of California, Los Angeles School of Medicine [I.L.T.), Los Angeles, California 90024
}

\begin{abstract}
We evaluated carbohydrate tolerance in nine thin cystic fibrosis (CF) patients and in six controls, measuring responsiveness to the following insulinotropic secretagogues: oral glucose, IV glucose, and IV tolbutamide. Glucose responses segregated patients into two groups: Group I with normal carbohydrate tolerance associated with normal to slightly increased insulin responses, and Group II with impaired carbohydrate tolerance associated with insulinopenia. This latter group included one patient
\end{abstract}

Received August 10, 1983; accepted April 13, 1984.

Correspondence may be addressed to Mitchell E. Geffner, M.D., Department of Pediatrics, UCLA Medical Center, Los Angeles, CA 90024.

This work was supported by United States Public Health Service Grant RR-865 and AM 21031 from the National Institutes of Health, and by grants from the Cystic Fibrosis Foundation, the Veterans Administration, CURE, and the American Diabetes Association. This was presented in part before the Joint Meetings of the Western Section, American Federation for Clinical Research, Western Society for Pediatric Research and Western Region, The Society for Investigative Dermatology, Carmel, CA, February 18, 1982, and at the Annual Meetings of the Society for Pediatric Research, San Francisco, CA, May 12, 1982. Published in part as abstracts in Clin Res 30:131 (1982) and Pediatr Res 16:258 (1982). with frank diabetes. The CF patients demonstrated a significant positive correlation between insulin secretion, in response to each secretagogue, and pancreatic exocrine function as measured by serum pancreatic amylase isoenzyme concentration. Pancreatic $\alpha$-cell function, as reflected by basal plasma glucagon concentrations, also correlated well with exocrine function in the $C F$ patients, excluding the diabetic individual. The enteroinsular axis of the CF group was intact as reflected by normal plasma gastric inhibitory polypeptide concentrations in Group I and by elevated levels, basally and in response to oral glucose, in the insulinopenic Group II patients. Furthermore, those patients with impaired tolerance demonstrated a greater magnitude of insulinopenia compared to controls following IV glucose and possibly IV tolbutamide, than following oral glucose.

Thus, these data suggest that loss of carbohydrate tolerance in patients with $\mathrm{CF}$, like that seen with classical chronic pancreatitis, 1) parallels the loss of exocrine function, 2) is associated with appropriate enteroinsular sig- 
naling, and 3) can be detected earlier or more easily following testing with direct IV secretagogues than following oral glucose stimulation. (Pediatr Res 18:1107-1111, 1984)

Abbreviations

CHO, carbohydrate

CF, cystic fibrosis

MA, mean age

$\mathrm{BW}$, body weight

GIP, gastric inhibitory peptide

RIA, radioimmunoassay

$P$, serum pancreatic

OGTT, oral glucose tolerance test

IVGTT, intravenous glucose tolerance test

IVTTT, intravenous tolbutamide tolerance test

CHO intolerance, as defined by an abnormal standard oral glucose tolerance test, has been reported to occur in as many as $50 \%$ of patients with CF $(10,18,26)$. An additional $8-15 \%$ of patients may become frankly insulin-dependent $(20,24)$. Suggested mechanisms to account for this $\mathrm{CHO}$ intolerance include disordered islet cell architecture due to extension of the destructive process occurring in the exocrine structures (10) and interruption of the enteroinsular axis signal for insulin release (5). The first implies that insulinopenia in CF results from strangulation of the islets as a result of progressive pancreatic fibrosis, as appears to be the case in some forms of pancreatitis (13). The second suggests that diminished insulin release is a consequence of a defect in the gastrointestinal system resulting in an abnormality of the enteroinsular axis (1). The present study was designed to clarify the role of these mechanisms and to determine the relative contributions of some of the factors which affect the functional dynamics of the endocrine pancreas. The data reveal: 1) a significant positive correlation between pancreatic endocrine function (both $\alpha$ - and $\beta$-cell) and pancreatic exocrine function as measured by $P$ amylase isoenzyme concentrations; 2 ) an intact enteroinsular axis in CF; and 3) loss of glucoreceptor-mediated insulin release prior to that of enteroinsular axis-mediated insulin release. These findings resemble the pattern of endocrine derangement seen in chronic pancreatitis.

\section{MATERIALS AND METHODS}

Patients. Nine CF patients from the University of California, Los Angeles, CF Center were studied after obtaining informed consent. In eight patients, there was no history of diabetic symptoms, glycosuria, or a first degree relative with known diabetes; one patient had a history of hyperglycemia during a recent hospitalization. The eight unselected patients had a MA of 24.5 \pm 2.2 years, mean BW of $48.6 \pm 4.4 \mathrm{~kg}$, and ideal BW of $63.4 \pm$ $3.1 \mathrm{~kg}$ (adapted from Metropolitan Life Insurance Company Actuarial Tables, 1959). The ninth patient (age 27 years, BW $42.5 \mathrm{~kg}$, ideal BW $56.8 \mathrm{~kg}$ ) had borderline fasting hyperglycemia $(119.4 \pm 4.2 \mathrm{mg} / \mathrm{dl})$ and elevated postprandial plasma glucose concentrations $(197.7 \pm 8.8 \mathrm{mg} / \mathrm{dl})$. Seven of these patients participated in multiple tolerance tests described below while the other two underwent oral glucose tolerance tests only. CF was diagnosed by appropriate history, a characteristic clinical course, and at least two sweat chloride measurements per patient of greater than $70 \mathrm{mEq} /$ liter.

Six volunteers (MA $29.8 \pm 2.3$ years; mean BW $63.2 \pm 5.4 \mathrm{~kg}$; ideal BW $61.6 \pm 5.5 \mathrm{~kg}$ ) served as controls. They had no history of CHO intolerance, chronic medical conditions predisposing to diabetes, or chronic medication use.

Tolerance tests. Following an overnight fast, testing was begun between 0800 and $0900 \mathrm{~h}$. In some patients, two intravenous tolerance tests were performed on the same morning with a $2-h$ rest period between tests; oral glucose tolerance was always tested alone on a separate day. The precedent for repeated intensive pancreatic $\beta$-cell stimulation was established by Vinik et al. (30), who concluded that responsiveness to oral glucose, glucagon, and tolbutamide was preserved both in normal subjects and in patients with chronic pancreatitis. In these patients, repeated stimulations yielded almost identical peak insulin responses presumably from release of an immediately available pool of stored insulin that could be rapidly replenished.

Oral glucose tolerance test. Following 3 days of $\mathrm{CHO}$ intake $(>150 \mathrm{~g} / 24 \mathrm{~h})$, each CF patient and six controls drank Glucola (Ames Division, Miles Laboratories, Inc., Elkhart, IN), $1.75 \mathrm{~g} /$ $\mathrm{kg}$ (maximum dose, $100 \mathrm{~g}$ ), over a $1-2-$ min period. Serial blood samples were obtained at $0,+30,+60,+120$, and $+180 \mathrm{~min}$ for glucose, insulin, and glucagon determinations in all patients. GIP levels were measured in five CF patients and five controls at the above designated times.

Intravenous glucose tolerance test. Patients received an infusion of $0.5 \mathrm{~g} / \mathrm{kg}$ of dextrose (maximum dose, $25 \mathrm{~g}$ ) over $2 \mathrm{~min}$. Serial blood samples for glucose and insulin measurement were obtained at $-30,-15,0,+2,+4,+10,+20$, and $+40 \mathrm{~min}$. In addition, plasma glucagon determinations were made at 0 and 20 min during this test. Six CF and five control subjects underwent the IVGTT.

Intravenous tolbutamide tolerance test. IV tolbutamide sodium (Orinase Diagnostic, The Upjohn Company, Kalamazoo, MI) was administered over $2 \mathrm{~min}$ at a dose of $15 \mathrm{mg} / \mathrm{kg}$ (maximum dose, $1 \mathrm{~g}$ ). Serial blood samples for glucose and insulin measurement were obtained at $-30,-15,0,+2,+4,+10,+20$, and +40 min. Plasma glucagon concentrations were measured at $-30,0$, $+10,+20$, and $+40 \mathrm{~min}$. Six CF and three control subjects underwent the IVTTT.

Laboratory methods. Plasma glucose concentrations were determined by ferricyanide reduction using a Technicon Autoanalyzer. Serum insulin concentrations were measured by standard double-antibody radioimmunoassay (28). Samples for plasma glucagon determinations were collected in benzamidine and EDTA, separated at $4^{\circ} \mathrm{C}$, and kept frozen until assay. Radioimmunoassay was performed using $30 \mathrm{~K}$ antiserum (6). Samples for plasma GIP determinations were collected in aprotinin and EDTA, separated at $4^{\circ} \mathrm{C}$, and kept frozen until assay. GIP-RIA was performed by a previously reported method utilizing rabbit antiserum at a final dilution of 1:7000 (17).

Serum amylase isoenzymes were separated using polyacrylamide disc gel electrophoresis and quantitated by gel densitometry according to a previously published procedure (8). The absolute concentration of $\mathbf{P}$ amylase isoenzyme was calculated by multplying the percentage of $P$ amylase isoenzyme present by the total serum amylase activity as measured by a modified saccharogenic procedure (7). All samples were obtained in the fasting state. The $95 \%$ normal range of $P$ amylase isoenzyme in our laboratory (age, 5-47 years) is 2.8-11.4 starch units/liter. CF patients with significant pancreatic insufficiency confirmed by duodenal intubation have values below the normal range after 1.5 years of age, while CF patients with adequate pancreatic function have values in or above the normal range. We have established that serum $\mathbf{P}$ amylase isoenzyme concentrations in CF patients correlate well with $72-\mathrm{h}$ fecal fat absorption and duodenal bicarbonate output, the standard tests for assessment of pancreatic exocrine function (9).

Statistical significance was determined by Student's $t$ test for paired or unpaired observations where appropriate. Correlation coefficients were determined by standard linear regression analysis. The above calculations, as well as compilation of integrated areas under insulin response curves, were performed using the HP-97 programmable printing calculator (Hewlett Packard, Corvallis, OR). All data are expressed as mean \pm SEM.

\section{RESULTS}

Following oral glucose ingestion, CF patients $(n=8)$ separated into two groups based on glucose responses: Group I was normal 
carbohydrate tolerance $(n=3)$ and Group II was impaired CHO tolerance $(n=5)$ (Fig. $1 A)$. The diabetic CF patient is depicted separately in this and subsequent figures. Although mean plasma glucose concentrations in Group I were greater than in controls at 60 and $120 \mathrm{~min}(p<0.001)$, these values were not within ranges considered to represent abnormal glucose tolerance for late adolescence (19). In Group II patients, mean plasma glucose concentrations were significantly greater than in controls at 30 $(p<0.05), 60$, and $120 \mathrm{~min}$ (both $p<0.001$ ). These Group II patients had 1 -h plasma glucose concentrations ranging between 188 and $284 \mathrm{mg} / \mathrm{dl}$ and 2 -h levels between 176 and $258 \mathrm{mg} / \mathrm{dl}$. The integrated glucose response in Group II $(32.3 \pm 2.18 \mathrm{~g} / \mathrm{dl}$. $\mathrm{min})$ was greater than that in Group I $(24.2 \pm 0.96 \mathrm{~g} / \mathrm{dl} \cdot \mathrm{min} ; p$ $<0.05)$ as were the mean plasma glucose responses at 60 and $120 \mathrm{~min}$ (both $p<0.05$ ). The diabetic CF patient had markedly abnormal glucose responses (Fig. 1A). When areas under the insulin response curve were compared, the mean area in Group I $(12.1 \pm 2.56$ milliunits $/ \mathrm{ml} \cdot \mathrm{min})$ was significantly greater than the mean of controls $(6.60 \pm 0.82$ milliunits $/ \mathrm{ml} \cdot \mathrm{min})(p<0.05)$. Contrastingly, the mean area under the insulin response curve in Group II subjects $(4.20 \pm 0.52$ milliunits $/ \mathrm{ml} \cdot \mathrm{min})$ was significantly less than that of controls $(p<0.02)$. This was a consequence of both decreased peak levels early in the test $(p<$ 0.02 at $30 \mathrm{~min}$ and $p<0.01$ at $60 \mathrm{~min}$ ) and delay in peak insulin responses until $120 \mathrm{~min}($ Fig. $1 B$ ). The least incremental insulin response was seen in the diabetic CF subject (2.15 milliunits/ $\mathrm{ml} \cdot \mathrm{min})$.

Following intravenous glucose, mean plasma glucose concentrations in both CF groups were not significantly different from those of controls (Fig. $2 A$ ). While Group I patients $(n=3)$ had a mean area under the insulin response curve $(2.23 \pm 0.81$ milliunits $/ \mathrm{ml} \cdot \mathrm{min}$ ) which was similar to that seen in controls $(1.43 \pm 0.25$ milliunits $/ \mathrm{ml} \cdot \mathrm{min})(p>0.05)$, Group II patients $(n=3)$ had significantly less insulin output $(0.36 \pm 0.027$ milliunit $/ \mathrm{ml} \cdot \mathrm{min})$ than did controls $(p<0.02)$ (Fig. $2 B)$. An unusual finding in two Group I patients was that their serum insulin concentrations remained elevated after $40 \mathrm{~min}$. The diabetic $\mathrm{CF}$ patient did not undergo this test.

In response to intravenous tolbutamide, the following mean plasma glucose decrements were observed: controls $(n=3) 44.3$ $\pm 3.30 \mathrm{mg} / \mathrm{dl}$; Group I $(n=3), 17.3 \pm 5.80 \mathrm{mg} / \mathrm{dl}$; and Group

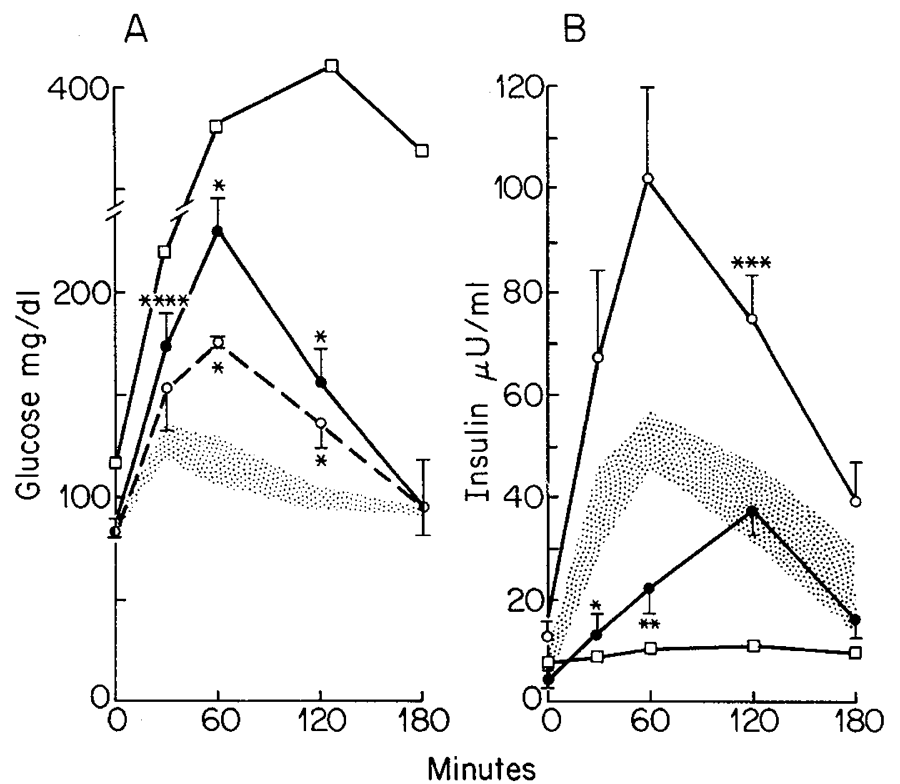

Fig. 1. OGTT results: glucose $(A)$, insulin $(B)$. CF group I (normal carbohydrate tolerance, $n=3$ ) is represented by $\mathrm{O}_{-}--\mathrm{O}$. CF Group II (impaired carbohydrate tolerance, $n=5$ ) is represented by The single diabetic CF patient is shown by $\square-\square$. Normal control data $(n=6)$ are shown in the stippled areas. ${ }^{*} p>0.001 ;{ }^{* *} p<0.01 ;{ }^{* * *} p$ $<0.02 ;{ }^{* * * *} p<0.05$ (all versus controls).
II $(n=3), 4.70 \pm 2.90 \mathrm{mg} / \mathrm{dl}$. Both the mean Group I decrement and the mean Group II decrement were significantly less than those of controls $(p<0.02$ and 0.001 , respectively) while there was no difference between Group I and Group II $(p>0.05)$ (Fig. $3 A$ ). The diabetic $\mathrm{CF}$ patient had a maximal decrement of 15 $\mathrm{mg} / \mathrm{dl}$ which was delayed in onset compared to the controls. Insulin responses of patients in Group I ( $1.34 \pm 0.25$ milliunits/ $\mathrm{ml} \cdot \mathrm{min})$ were similar to those of controls $(1.43 \pm 0.67$ milliunits/ $\mathrm{ml} \cdot \min )(p>0.05)$. Although mean area under the insulin response curve was lower in Group II patients $(0.54 \pm 0.056$ milliunit $/ \mathrm{ml} \cdot \mathrm{min}$ ), this was not statistically different from either controls or Group I $(p>0.05)$ (Fig. $3 B)$. Again, the least incremental insulin response was seen in the one diabetic subject (0.39 milliunit $/ \mathrm{ml} \cdot \mathrm{min})$.

Pancreatic exocrine function was assessed by determination of $P$ amylase isoenzyme levels and then correlated to insulin and glucagon activity. The relationship between $P$ amylase isoenzyme concentration and insulin secretion in response to the three insulinotropic secretagogues is shown in Figure 4, $A-C$. In the CF patients, a significant correlation is demonstrated for each agent: oral glucose $(n=9)(R=0.92, p<0.001)$; IV glucose $(n$ $=5)(R=1.00, p<0.001)$; and IV tolbutamide $(n=6)(R=$ $0.93, p<0.01)$. No correlation between insulin secretion and $\mathrm{P}$ amylase isoenzyme levels was evident in the control population $(p>0.05)$, although control values tended to fall between those of the two CF groups.

Evaluation of pancreatic $\alpha$-cell function demonstrated that the basal plasma glucagon concentrations in the eight nondiabetic CF patients also showed significant positive correlation with their $\mathrm{P}$ amylase isoenzyme concentrations $(R=0.87, p<0.01)$ (Fig. $5)$. Again, control values were intermediate with no specific

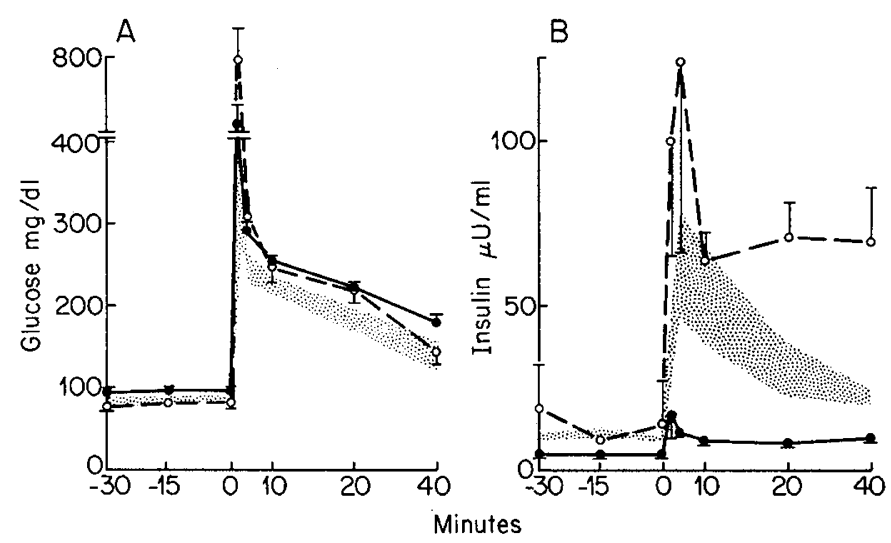

Fig. 2. IVGTT results: glucose $(A)$, insulin $(B)$. Group I $(n=3)$, Group II $(n=3)$, and controls $(n=5)$ are represented by the symbols used in Figure 1.

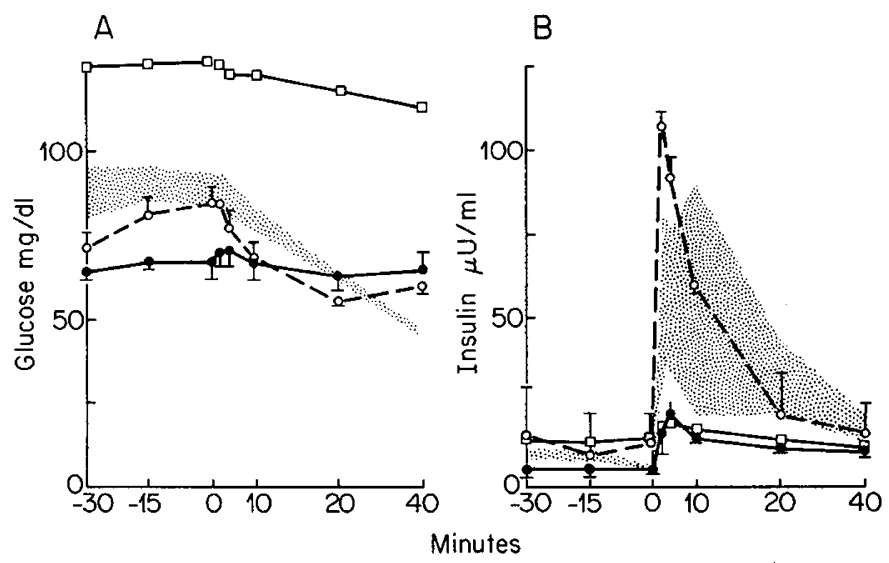

Fig. 3. IVTTT results: glucose $(A)$, insulin $(B)$. Group I $(n=3)$, Group II $(n=3)$, and controls $(n=3)$ are represented by the symbols used in Figure 1. 

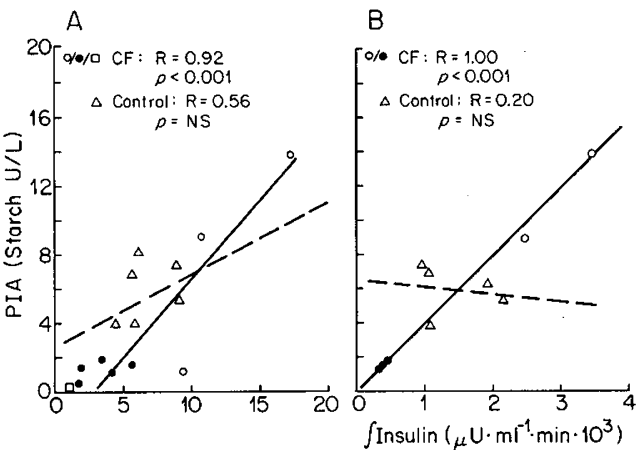

C

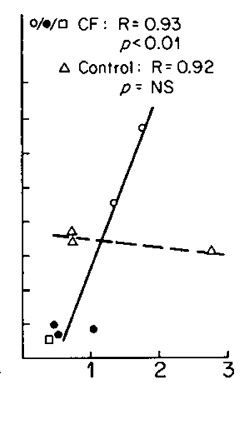

Fig. 4. Correlation of insulin secretion with pancreatic exocrine function. Insulin secretion is defined as the area under the insulin response curve following the administration of oral glucose $(A)$, intravenous glucose $(B)$, and intravenous tolbutamide $(C)$. Exocrine function is quantitated by the serum pancreatic amylase isoenzyme concentration.

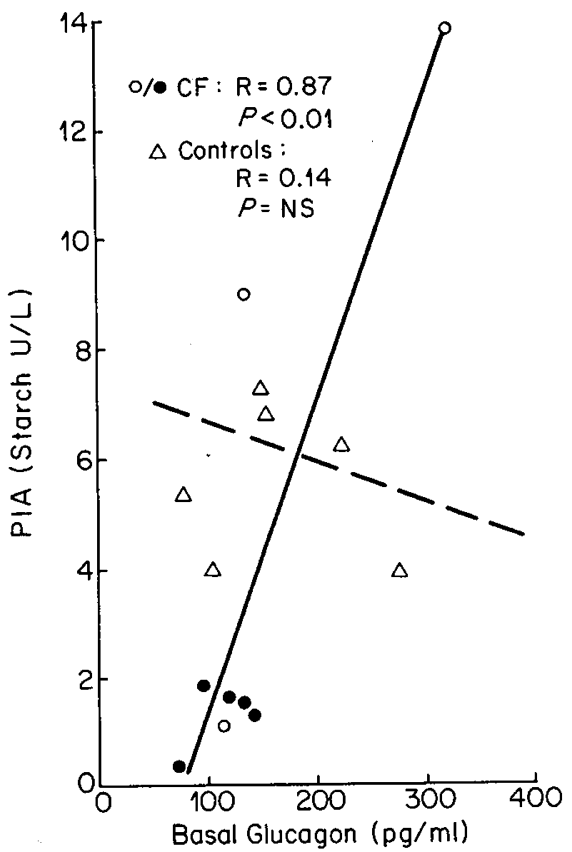

Fig. 5. Correlation of mean basal plasma glucagon concentrations with pancreatic exocrine function.

correlation of $\mathrm{P}$ amylase isoenzyme and basal glucagon $(p>$ 0.05 ). The one diabetic $C F$ subject had a mean basal plasma glucagon concentration of $337 \pm 62 \mathrm{pg} / \mathrm{ml}(n=3)$.

To quantitate enteroinsular axis function, GIP: insulin ratios following OGTT were correlated (Table 1). The GIP:insulin ratios in the two Group II carbohydrate-intolerant patients were greater than 3SD above the mean control value, whereas there was no significant difference between the two Group I patients and controls. Additionally, a relatively greater impairment (mean of $75 \%)(p<0.02)$ of insulin secretion was seen in Group II patients versus controls following IV glucose than following both oral glucose (mean of $36 \%)(p<0.02)$ and IV tolbutamide (mean of 62\%) $(p>0.05)$ (Fig. 6).

\section{DISCUSSION}

In the nine $\mathrm{CF}$ patients studied herein, we have demonstrated two general patterns of CHO tolerance in response to insulinotropic secretagogues: normal $\mathrm{CHO}$ tolerance with appropriate to exaggerated insulin responses (Group I) and decreased $\mathrm{CHO}$ tolerance associated with insulinopenia (Group II), with one patient manifesting a frankly diabetic pattern. That these heterogeneous insulin responses may be due to variation in residual pancreatic integrity is suggested by the significant positive correlations observed between $\mathrm{P}$ amylase isoenzyme concentrations and insulin secretion. This parallel dysfunction of pancreatic exocrine function and $\beta$-cell activity in CF patients is supported by the recent studies of Antonelli et al. (2), who used serum immunoreactive trypsin and fasting C-peptide concentrations to assess pancreatic exocrine and endocrine functions, respectively.

Basal $\alpha$-cell function in our patients, as assessed by mean fasting plasma glucagon concentrations, correlated significantly with $\mathrm{P}$ amylase isoenzyme concentrations in these patients, excluding the diabetic individual. We and others have previously

Table 1. Enteroinsular axis in CF following oral glucose administration

\begin{tabular}{cccc}
\hline $\begin{array}{c}\text { Patient } \\
\text { group }\end{array}$ & $\begin{array}{c}\text { Area under GIP } \\
\text { curve }\left(\mathrm{A}_{\mathrm{GIP}}\right)\end{array}$ & $\begin{array}{c}\text { Area under } \\
\text { insulin curve } \\
\left(\mathrm{A}_{\mathrm{I}}\right)\end{array}$ & $\begin{array}{c}\mathrm{A}_{\mathrm{GIP}} / \\
\mathrm{A}_{\mathrm{I}}\end{array}$ \\
\hline CF Group I & & & \\
1 & 34,080 & 8,550 & 3.99 \\
2 & 42,458 & 17,055 & 2.48 \\
CF Group II & & & \\
1 & 301,635 & 3,855 & 78.2 \\
2 & 290,805 & 3,345 & 86.9 \\
Controls & & & \\
1 & 41,552 & 8,070 & 5.1 \\
2 & 70,320 & 4,260 & 16.5 \\
3 & 80,265 & 5,820 & 13.8 \\
4 & 94,905 & 9,060 & 10.5 \\
5 & 55,388 & 7,500 & 7.4 \\
& & & \\
Mean & $68,487 \pm 9,319$ & $6,942 \pm 852$ & $10.7 \pm 2.06$ \\
\hline
\end{tabular}

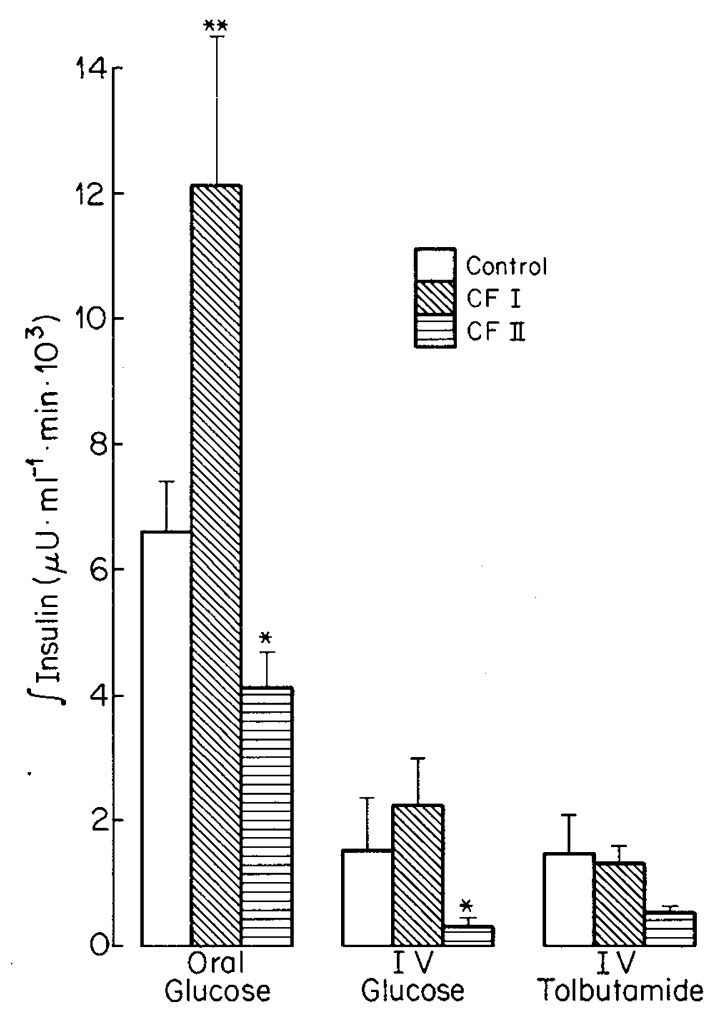

Fig. 6. Relative potency of insulinotropic secretagogues. The vertical axis represents the integrated area under the insulin response curve. Note the greatest difference between hypoinsulinemic Group II CF patients versus controls following IV glucose (mean decrement $75 \%$ ) compared to that seen following either oral glucose (mean decrement $36 \%$ ) or following IV tolbutamide (mean decrement $62 \%$ ). ${ }^{*} p<0.02 ;{ }^{* *} p<0.05$ versus controls. 
noted that hyperglucagonemia is not a feature of mild carbohydrate intolerance in CF (16), but may be present in markedly insulinopenic $C F$ patients $(23,29)$ and in patients with pancreatitis (11). We interpret these data to suggest that ambient plasma glucagon concentrations are suppressed by the interaction between glucose and insulin over a range of pancreatic insufficiency. However, when insulin loss is profound, hyperglucagonemia supervenes, suggesting preservation of some residual $\alpha$ cell activity. Since one Group I CF patient also showed a dissociation between the $\mathrm{P}$ amylase isoenzyme concentration and insulin responsiveness, demonstrating low exocrine reserve with normal insulin levels, the data suggest that exocrine dysfunction precedes $\beta$-cell loss and that $\beta$-cell precedes $\alpha$-cell loss.

Of note is that the plasma glucose responses during the IVGTT and the IVTTT were similar in Groups I and II despite markedly different insulin responses. Thus, the hypoinsulinemic patients disposed of IV glucose as effectively as the normoinsulinemic group. While thin hypoinsulinemic CF patients may have enhanced insulin sensitivity by virtue of increased receptor number (15), glucose disposal might be expected to be similar after oral and IV glucose. In fact, if differences occur, recent evidence in normal man suggests that glucose ingested orally is disposed of more efficiently than glucose administered intravenously (22). Ten to $15 \%$ of oral glucose can be taken up by the liver on first passage (27). If liver dysfunction develops, which is a common occurrence in $\mathrm{CF}(21)$, peripheral disposal of an intravenous load of glucose may be normal whereas disposal of an orally ingested load could be delayed. Thus, Group I patients, with greater insulin output than that of controls following oral glucose ingestion, may be responding to diminished hepatic insulin sensitivity secondary to associated liver damage.

Although GIP concentrations in CF have been reported as exaggerated in response to oral glucose (25) and diminished following a milk stimulus (1), our data suggest that there is an appropriately functioning enteroinsular axis with normal GIP responses in the CHO-tolerant Group I patients and enhanced basal and oral glucose-stimulated levels in CHO-intolerant Group II, similar to that seen in chronic pancreatitis (4). These results confirm the negative feedback relationship proposed for GIP and insulin (3). Both previously cited CF studies reported only insulinopenic patients and the latter study relied on intestinal hydrolysis of milk fat for stimulation of GIP secretion. Although all patient groups showed decreased insulin secretion in response to IV glucose compared to oral glucose or IV tolbutamide, Group II CF patients produced significantly less insulin after IV glucose than after oral glucose compared to respective control responses. This suggests earlier or greater loss of glucoreceptor activity compared to "enteroreceptor" (GIP) activity. Although we did not find statistically different responses to IV tolbutamide between patient groups or compared to controls, which may reflect small sample size, loss of insulin responsiveness to tolbutamide in Group II was intermediate between that seen with oral and IV glucose.

Thus, our studies suggest that the pancreatic endocrine disturbances in $\mathrm{CF}$ may be similar to those described in chronic pancreatitis, supporting the disruption hypothesis. The degree of insulinopenia appears to mirror the degree of exocrine insufficiency. Similarly, insulinopenia, associated with diminished content of amylase, chymotrypsin, and lipase in pancreatic juice following cholecystokinin-pancreozymin stimulation in seven patients with chronic pancreatitis, has been reported by Kalk et al. (14). Additionally, loss of $\beta$-cell receptor recognition of intravenous glucose, and possibly tolbutamide, may antedate loss of sensitivity to enteroinsular (GIP) mediated insulinotropic secre- tagogues in our CF subjects and in patients with chronic pancreatitis (12).

\section{REFERENCES}

1. Adrian TE, McKiernan J, Johnstone DI, Hiller EJ, Vyas H, Sarson DL, Bloom SR 1980 Hormonal abnormalities of the pancreas and gut in cystic fibrosis. Gastroenterology 79:460

2. Antonelli M, Quattrucci S, Bravo E, Dominici R, Maceli F, Antonozzi I 1981 Exocrine and endocrine pancreatic function tests in cystic fibrosis. Monogr Paediatr 14:166

3. Beck B, Villaume C, Debry G 1982 Clinical aspects of GIP secretion. Acta Diabetol Lat 19:1

4. Botha JL, Vinik AI, Brown JC 1976 Gastric inhibitory polypeptide (GIP) in chronic pancreatitis. J Clin Endocrinol Metab 42:791

5. Brown JC, Otte SC 1978 Gastrointestinal hormones and the control of insulin secretion. Diabetes 27:782

6. Faloona GR, Unger RH 1974 Glucagon. In: Jaffe BM, Behrman HR (eds) Methods of Hormone Radioimmunoassay. Academic Press, New York, pp $317-330$

7. Fisher EH, Stein EA $1961 \alpha$-Amylase from human saliva. Biochem Prep 8:27

8. Gillard BK 1979 Quantitative gel-electrophoretic determination of serum amylase isoenzyme distributions. Clin Chem 25:1919

9. Gillard BK, Cox KL, Pollack PA, Geffner ME 1984 Cystic fibrosis serum pancreatic amylase: useful discriminator of exocrine function. Am J Dis Child 138:577

10. Handwerger S, Roth J, Gorden P, Di Sant'Agnese P, Carpenter DF, Peter G 1969 Glucose intolerance in cystic fibrosis. N Engl J Med 281:45

11. Kalk WJ, Vinik AI, Bank S, Buchanan KD, Keller P, Jackson WPU 1974 Glucagon responses to arginine in chronic pancreatitis. Possible pathogenic significance in diabetes. Diabetes 12:257

12. Kalk WI, Vinik AI, Bank SA, Keller P Jackson WPU 1974 Selective loss of beta cell response to glucose in chronic pancreatitis. Horm Metab Res 6:95

13. Kalk WJ, Vinik AI, Jackson WPU, Bank S 1979 Insulin secretion and pancreatic exocrine function. Diabetologia 16:355

14. Kalk WJ, Vinik AI, Jackson WPU, Bank S 1979 Insulin secretion and pancreatic exocrine function in patients with chronic pancreatitis. DiabetoJogia $16: 355$

15. Lippe BM, Kaplan SA. Neufeld ND, Smith A, Scott M 1980 Insulin receptors in cystic fibrosis: increased receptor number and altered affinity. Pediatrics 65:1018

16. Lippe BM, Sperling MA, Dooley RR 1977 Pancreatic alpha and beta cell functions in cystic fibrosis. J Pediatr 90:751

17. Maxwell V, Shulker A, Brown JC, Solomon TE, Walsh JH, Grossman MI 1980. Effect of gastric inhibitory polypeptide on pentagastrin-stimulated acid secretion in man. Digest Dis Sci 25:113

18. Milner AD 1969 Blood glucose and serum insulin levels in children with cystic fibrosis. Arch Dis Child 44:351

19. National Diabetes Data Group 1979 Classification and diagnosis of diabetes mellitus and other categories of glucose intolerance. Diabetes 28:1039

20. National Institute of Arthritis, Metabolism, and Digestive Diseases 1979 Cystic fibrosis: a disease in search of ideas. In: Clinical Sciences, vol 2. National Institutes of Health Bethesda, MD, pp 33-34, DHEW Publication No (NIH)79-643

21. Psacharopoulos HT, Portmann B, Howard ER, Mowat AP, Williams R 1981 Hepatic complications of cystic fibrosis. Lancet 1:78

22. Radziuk J, Inculet R 1983 The effects of ingested and intravenous glucose on forearm uptake of glucose and glucogenic substrate in normal man. Diabetes $32: 977$

23. Redmond AOB, Buchanon KD, Trimble ER 1977 Insulin and glucagon responses to arginine infusion in cystic fibrosis. Acta Paediatr Scand 66:199

24. Rodman HM, Matthews LW 1981 Hyperglycemia in cystic fibrosis: a review of the literature and our own patient experience. In: Warwick WJ (ed) 1000 Years of Cystic Fibrosis. Collected Papers. Presented at an international conference on cystic fibrosis at the University of Minnesota, St. Paul Campus, May 7-9, 1981, pp 67-76

25. Ross SA, Morrison D, McArthur RG 1981 Hypersecretion of gastric inhibitory polypeptide in nondiabetic children with cystic fibrosis. Pediatrics 67:252

26. Selden RF Jr, Bennett MJ, Paulsen EP 1976 Evidence for altered beta cell sensitivity to stimuli as a basis for poor insulin release in cystic fibrosis. Paper presented at Seventeenth Annual Meeting of Cystic Fibrosis Club, National Cystic Fibrosis Research Foundation, Saint Louis, MO

27. Sherwin RS 1980 Role of the liver in glucose homeostasis. Diabetes Care 3:26

28. Soeldner JS, Slone D 1965 Critical variables in the radioimmunoassay of serum insulin using the double antibody technique. Diabetes 14:771

29. Stah1 M, Girard J, Rutishauser M, Nars PW, Zuppinger K 1974 Endocrine function of the pancreas in cystic fibrosis: evidence for an impaired glucagon and insulin response following arginine infusion. $J$ Pediatr 84:821

30. Vinik AI, Kalk WJ, Botha JL, Jackson WPU, Blake KCH 1976 The inexhaustible beta cell. Diabetes 25:11 